\title{
鉄道事故の分析と対策*
}

一ヒューマン・エラーをめぐって--

\section{池田 敏久**}

\section{1. はじめに}

“鉄道の歴史は事故の歴史である”と評されるように， 日本に限っても 100 年以上の歴史をもつ鉄道は早くから いくつかの大事故を経験し, 安全性向上てそを唯一の目 標に各種のシステム改善を進めてきた.

近年，鉄道事故は相当に抑制され，鉄道は他の交通機 関との比較でも遴色のない水準に成長している（表 1 ）. しかし，大事故の危険性はなお残されている一方で，鉄 道システムは運転の高頻度化, 列車の多様化, 運営の省 力化・省エネルギー化などの強い要請をうけて急速な変 革を続けており，“安全・高質な交通機関”に成熟する ための新しいシステム・アセスメントの確立が強く期待 されている.

こてでは国鉄の動力車乗務員のエラーに焦点をあてな がら，鉄道システムと鉄道事故の特徴，事故分析と事故 対策の現状, 鉄道安全の将来について展望してみたい.

\section{2. 鉄道システムと鉄道事故の特徴}

他の交通機関と比較した鉄道の特異性は“ガイドウェ イ方式”であるという 1 点に集約される. ガイドウェイ であること,つまり列車自体に方向制御の機能がないて とは, “方向制御の失敗による事故がない”という際立 った利点である反面, “障害をハンドルで回避できない” という安全上の宿命的な欠点でもある.

ここに注目して，まず，鉄道システムと鉄道事故の特 徽を見てみよう。

* 昭和 55 年 4 月 1 日受付

** 国鉄・鉄道労㗢科学研究所

Railway Labour Science Research Institute, JNR.

\section{2-1. 鉄道システム(1)一安全の確保}

ガイドウェイ方式での致命的な事故は, 列車同士の衝 突と, オーバーランによる列車の脱線である.てれを防 ぐために，鉄道では古くから“閉そく（塞）”という鉄則 を設けている，乙れは, 線路をブロック分けして“1つ のブロックには 2 つ以上の列車を進入させない”という 方法である. 閉そくを保証するものは入口に設けられる “信号”であり “ $\mathrm{R}<$ 停止>区間（ここには他列車が存 在するか, 進路が構成されていない）には絶対に列車を 淮入させない”こととしている．R区間の手前には必ず $\mathrm{Y}<$ 注意, 制限 $45 \mathrm{~km} / \mathrm{h}>$ 区間, さらにG<進行>区間 が置かれ，列車には少なくともこの 2 つの区間を隔てて 運転させ，R区間に対しては必ず“過走余裕距離 $(50 \mathrm{~m}) ”$ を残した地点に停止させる仕組みとしている. さらに行 き違い駅ではオーバーランによる列車の衝突を防ぐた め, 信号装置に 2 列車の同時進入を忍めない連動機構ま たは “安全側線”（オーバーランした列車をわざわざ脱 線させて衝突を抑止する設備）が設けられている. 信号 に, いわゆるフェール・セーフ機構が備えられているこ とはいうまでもない.

表 1 交通機関の安全性比較 ${ }^{7}$

\begin{tabular}{l|r|r|r}
\hline 交通機関 & $\begin{array}{c}\text { 輸送量 } \\
(\mathrm{A})\end{array}$ & $\begin{array}{c}\text { 死亡者 } \\
(\mathrm{B})\end{array}$ & \multicolumn{1}{c}{$\begin{array}{c}\text { 事故率 } \\
(\mathrm{B} / \mathrm{A})\end{array}$} \\
\hline
\end{tabular}

注）1. 1968～1977年度の10年間の実績を示す.

2. 輸送量は「運輸白書」による.

3. 死亡者は“乗客・乗員の事故死”を計上し, 国 鉄は「運転事故統計」, 私鉄は「民鉄統計年報」, 自動車・航空機は「交通安全白書」による. 




注） $1.1968 \sim 1977$ 年度の10年間の実績を示す.

2. “取り扱い誤り”の分類では，同一事故に 2 人以上の詋りが計上される ものがあるため, 図中, 前半の数优は延べ䛇り数に対する\%, 後半の数㑬! は事故件数に対する\%示した。

もう1つの主要な危険は, 速度超過による列車の脱線 または転覆である、てれを防ぐため, 鉄道では線路と車 両の性能に静的, 動的なきわめて高い安全率をとった各 地点の制限速度を設定しててれを基に各列車の “基準走 行速度曲線”を規定し運転速度を細かく規制する一方, 脱線防止ガード・レール（曲線部，踏切に設置)，線間 離隔の拡大，線間防護装置の設置などによって脱線の防 止と被害の抑制をはかっている.

閉そくの鉄則と速度の規制はシステムが故障した場合 にはさらに笅格となり, “ポイントの機械的鎖錠”，“人 間タブレット方式” “運転速度 $25 \mathrm{~km} / \mathrm{h} ”$ の 3 原則の下 で運転される.

こうした仕組みのなかで, 動力車乗務員は, 列車の衝 突・脱線の回避関して，まず

(1) “閉そく冒進”の防止一一信号の識別・確認によ る許容地点以前での停止

(2) “速度超過”の防止一一地上の標識と運転台の仕 業表の確慧に上る速度制限地点（曲線, ポイント, 勾 配および工事中の徐行区間) での抑速, 許容された最 高速度の遵守

を義務づけられ，さらに

（3）異常の看視と緊急停止——前方(線路, 踏切など) と車両機器の看視による異常時の緊急停止

(4) 事故時の 2 次災害の防止

を期待されている.

\section{2-2. 鉄道システム(2)—運行の管理}

つぎに“運行管理”面での特徴を見てみる。

ガイドウェイ方式である鉄道のもう1つの宿命は，列 車の行き違い・待避の場所がでく限定されるため, 各列 車を無統制に運行させた場合には随所で “閉そく待ち” が生じ，効率が極度に低下することである．また，駅中 間で列車が故障，停止した場合には，その線区の交通は ほほ全面的に途絶する.

このため，鉄道では“列車ダイヤ”と“運行管理”に 相当な関心を払っている. 列車ダイヤはさきの基準走行 速度曲線に一定の余裕を与えて構成されるが，乙れは列 車の着発時刻, 運転順序, 着発番線, 行き違い・待避場 所を指定するだけでなく，線区全体の運転作業命令とい う性格をもち，ポイトの制御，駅の入れ替え，線路の 保守などすべての作業がてれに基づいて進められる.

列車ダイヤは “指令当直”によって常時監視され，列 車や地上作業が一定時間（10分程度）以上遅れた場合に は指令当直によって変更され，すべての関係者に指令さ れる. 故障時の運転方法や救援, 復旧の指令も指令当直 から出される.
動力車乗務員は
(1) 列車ダイヤに忠実な列車の運行
（2）指令内容の迅速, 正確な実行

を強く要求され，その職務は全般的に見て自律性が相当 
低く，時間的，空間的に強く規制された連続的監視・追 従作業の色合いを濃く帯びている.

\section{2-3. 鉄道事故}

つぎに，最近の鉄道事故を見てみる，国鉄では各種の 事故のうち大事故への拡大の危険性が特に高いものを “列車事故”之呼び最も警戒しているが，現在において もその大半は “列車脱線” と “列車衝突” で占められて おり（図 1)，鉄道がガイドウェイ方式という欠点にな お苦悩している事実が明白である.

事故の約半数は “取り扱い誤り” と “踏切事故”（乙 の大部分はドライバーのエラーによる）を契機としてお り，ヒューマン・エラーに対するシステムの改善が当面 の重点課題といえる. 取り扱い誤り事故の過半数に関与 している“動力車乗務員”に注目すると“閉そく冒進” （“信号確認㔖り”と“ブレーキ扱い誤り”の合計）が 実に $83.8 \%$ ，次いで “速度超過”が $6.7 \%$ で，主として 動力車乗務員に期待してきた閉そく冒進と速度超過の防 止機能を根本的に再検討した事故対策の確立が望まれて いる.

\section{3. 鉄道事故の分析}

現在進められている鉄道事故の分析は，個々の事故を 発生直後に現地調查して行う “事例分析” 生した類似の事故および準事故群の報告データや新たに 収集した調查実験データをもとに行う“大数分析”とに 大別される．前者では “原因の究明”に，後者では “対 策の提案”に重点が扔かれているように思われる。ただ し，後者は制度的に規定されたものではないため，てて では前者について紹介する.

\section{3-1. 事故調查}

ある駅で列車脱線事故が発生したとする，現地からの 第 1 報は指令当直に入る. 指令当直は鉄道管理局（現業 機関を管理する地方組織）運転部保安課の “調査スタッ フ”（各系統の実務経験者から選ばれ一定の事故調査教 育を受けた専従者）に緊急出動を要請する。

現地に急行した調査スタッフは

（1）現象調査一一脱線の状況, 線路や車両の傷痕, ポ イント・信号装置の状況，運転室や車両機器の状況の 外形的な調查

（2）供述調査一一動力車乗務員，車掌など全関係作業 者との個別面接による, 各自の作業経過の調查, 作業 記録の点検
（3）機能試験——ポント・信号装置, 車両機器など 関係機器装置の動作試験

を行い, 調査資料を管理局に電送する.

このあいだに運転部長を長とする “調査分析チーム” が管理局内に編成され，原因の究明にあたる.

調査と分析が “実証主義”をとるてとはいうまでもな い. 調査分析チームは現地からの調査資料を整理, 照们 して, 久落や疑義のある部分については調查スタッフに 再調査を指示する.さらに疑問や矛盾が残る場众は, “再現実験”（事故当時の設備条件と作業過程を忠农に再 現して計測データを収集する総合試験）を行う。

\section{3-2. 事故分析}

以上の調査資料を基に調查分析チームは事故の湶风を 解明し，所定の梯式による報告書（“種別”，“日時，天 候”, “場所”, “列車”, “概㫛”, “原因”, “関係者”, “関 係者の取り扱い（または供述）”，“対策”，“参考事項”在 骨子とする）を取りまとめ，管理局の“事故防止対策委 員会”（管理局長を長とする管理局内の安全問題の最高 審議機関＜常設〉）の承垫在得て, 本社に報告する. ま た，その主要な情報を集中管理するための別途様式によ るデータ・シートを送付する（原調査資料は管理局で保 存).

報告を受けた本社は，事故の最終的な検討を行う。報 告書は “運転局保安課” (事故分析・事故対策を専門的 に扱う課）の専門調查スタッフの検討をうけて補足され たのち

（1）“運転事故防止対策委員会速報事故検討会” (保安 担当常務理事を長とする専門検討スタッフく常設 $>$ )

（2）“運転事故防止対策委員会”（総裁を長とする灾 全問題の最高審議機関<常設 $>$ )

にかけられ，分析に不十分な点があれば管理局は再分析 を指示される。解明が最終的に困難なものについては

(3) “運転事故防止対策委員会専門委員会”（(2)の分 科会で，特定の問題を専門的に分析して対策在桇子 万機関 <常設 $>$, 現在 “踏切対策専門委員会” 11 の委員会がある)，または特別に没置される “つつ年 故技術調查本部”

亿付託され，長期的，総合的な技術調查が行われ心。

これらの分析結果のうち特に必要なものは

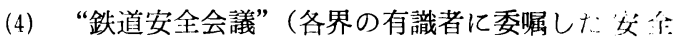

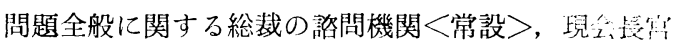
城音弥氏）

に紹介され，国鉄の安全性向上に対する助言が水沙られ ろ. 


\section{3-3. 事故分析の問題点}

“当事者企業だけで行われている”という批判はある が9)，実証主義と再審議制を基調とする国鉄の事故調 査・分析体制は一応定着しており，ヒューマン・エラー を契機としない事故についてはほほ十分に機能している と見られる。

しかし，ヒューマン・エラーに起因するものについて は必ずしも十分には機能していない，その根源的な理由 は，ヒューマン・エラーの当事者に “職務上の注意義務 違反”の責任を問う制度が存在するてとである．列車脱 線などの大事故では，当事者は直ちに拘留され警察の事 情聴取を受ける，起訴され，有罪の判決を受ける例も少 なくない，起訴されない場合でも，当事者の大部分は事 故の “責任者”として，企業の服務規定と賞魝規定に照 らした部内処分を受ける．また，公共輸送機関の宿命と して，現場の復旧と運転の再開を特に急がれるという点 も，詳細な調查や現場の保存の障害となっている.

こうした背景の下での事故調査・事故分析の主な問題 点をあげると

（1）事故関係者（および彼らの所属する職場，系統， 労働組合）が責任の帰すうを考えて自己防衛的になり やすく，真相が歪められるおそれがある

（2）当事者が拘留されるため，もっとも重要な初期調 查が円滑に進みにくい

（3）現場の復旧と運転の再開を急がれるため，調査が 皮相的になりやすく，現場の保存も十分に行われにく い

（4）上部組織，報道機関などから “原因” の特定を急 がれるため, 調査が“予断”をもって進められる危険 がある

（5）報告書で事故の “発生経過”と “原因” の特定が 強く求められるため, 論理的に明快な想定だけが重視 され，考えられる他の可能性が捨象されやすい

（6） システムの複雑高度化に即応する第 1 線調查スタ ッフの教育, その陣容が十分でない

などである.

ヒューマン・エラーに関しては，伝統的な “事故分 析”が 1 つの壁に直面している現状を否定できない。

\section{4. 鉄道事故の対策}

鉄道の事故対策は，個々の事故に対する “緊急対策” とシステム改善を目的とする “長期対策”とに大別さ れ, 前者は “事例分析” から, 後者は “大数分析” から
提案される。乙れらは本社および管理局の “事故防止対 策委員会”で決定され，実施されるが，鉄道の安全性向 上は基本的には後者によっている。

まず，主な内容について見てみる。

\section{4-1. エラー予防対策}

ヒューマン・エラーに関する事故対策として古くから 進められているものは“エラーの発生率を下げる”てと を目標としたもので，現在

(1) 資格試験一一定の職務経験を条件とする専門的 知識・技能武験に上る選抜

（2）適性管理——採用時，登用時および一定周期でと の医学・心理適性検査の実施とこれに基づく管理 指 導

（3）養成教育，指導訓練，動機づけ一一採用時，登用 時，転換時の教育機関による養成教育および定期的な 職場内指導訓練（机上，シミュレータ，実車の訓練， 添乗指導など)

（4）作業手順の改善—取り扱い規程の改正（3 力年 ごと)，作業マニュアルの整備

（5）仕業交番の改良一生理心理的負担の適正化と機 能水準維持を目的とした交替・休䕀制の改善

（6）機器の作業性改善——表示類の改良と整備, 機器 の操作性向上

（7）環境諸条件の改善——運転室環境の改善，宿泊· 休镍施設の充実など などが実施されている.

これらの流れを振り返ってみると1940年代までは(1), (3)，(4)が主軸で，50６0年代に(2)，60年代に(5)，60７0 年代に(6)と(7)の大きな進展が見られる. 社会一般の技術 的, 経済的な発展と安全に対する要求水準の向上を反映 して, 事故対策はより科学的かつ広範囲に展開されてい ろ.

\section{4-2. バック・アップ対策}

鉄道の事故対策のもう1つの流れは，エラーが発生し てもてれを事故に結びつけないてとを目的とする“バッ ク・アップ対策”である。これは人間行動の信頼性に関 す万人間科学的な認識の浸透々自動制御技術の飛躍的な 発展をうけて，1960年代以降に急速に挔充されてきた.

動力車乗務員のエラーに上る “閉そく冒進”之“速度 超過” に対する導入，拡充の歴史は図 2 に要約される が, 前者に限っても

（1） R信号に対する “車内警報装置” の設置— $\mathrm{R}$ 信 号の手前一定距離の地点で運転室に警報を発信 


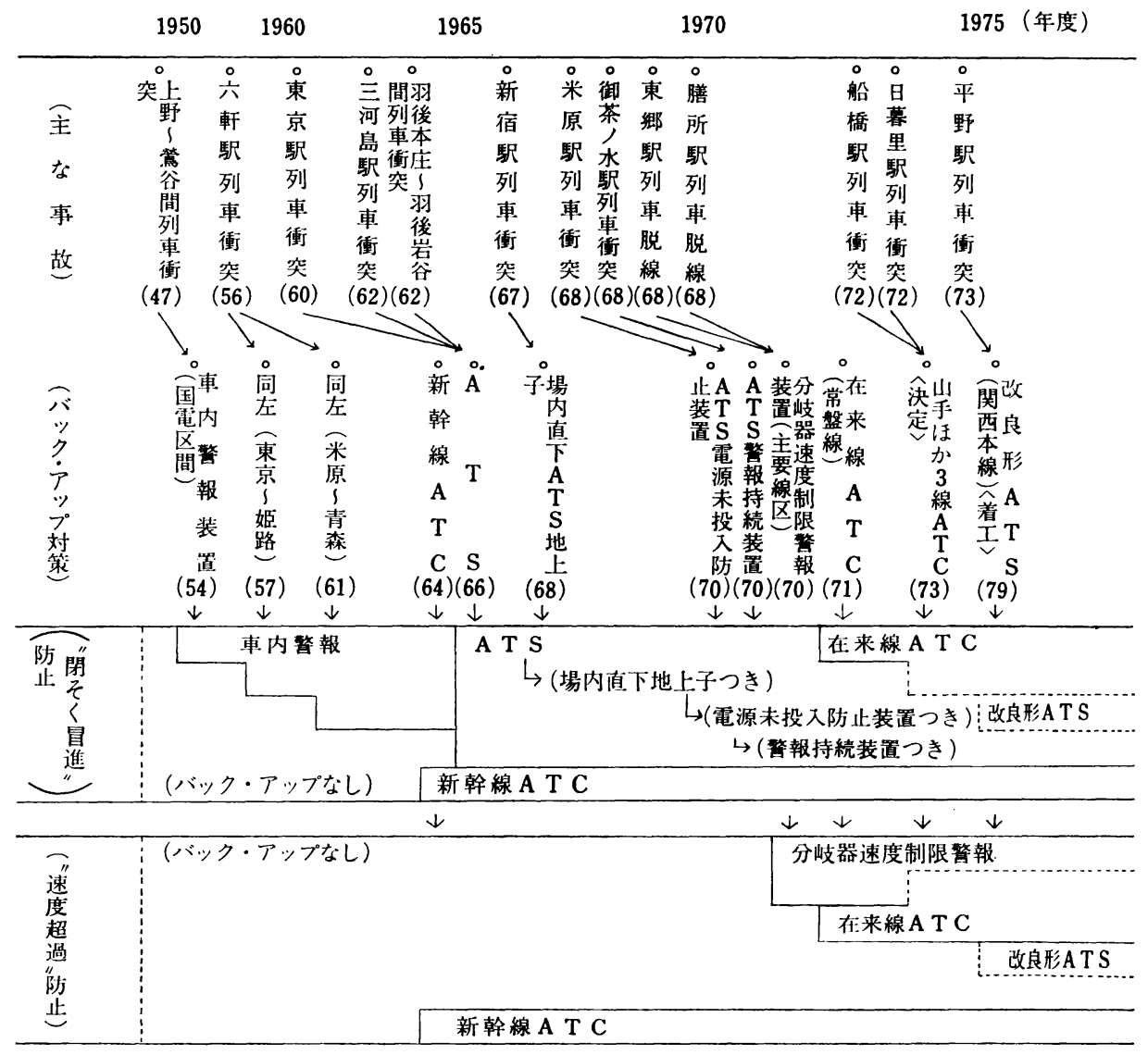

注）“主な事故”，“バックアップ対策”の（）内の数值は発生年度または設置年度を西歴で示す.

図 2 国鉄における “バック・アップ対策” の拡充経過》上り作四

（2）“ATS（自動列車停止装置）”の設置—(1)の 装置に, 一定時間 ( 5 秒間) 動力車乗務員の応答操作 （ブレーキを操作したあとの確認ボタンの圧下）がな ければ列車を自動的に非常停止させる機能を付加. 確 認ボタン圧下後は機能消㓕

（3）“ATS 電源末投入防止装置” の付加

（4）“ATS 警報持続装置” の付加一(2)の装置に確 認ボタン圧下後も“警報中”であるととを警告する表 示を付加（ただし自動停止機能そのものは消㓕）

（5）“改良型 ATS 装置”の開発一一確認ボタンを 排除し，R区間に進入する危険をもつ高速度運転の列 車を自動的に非常停止

という機能拡大を経て, 現在では

(6) “ATC (自動列車制御) 装置” の開発, 導入一 信号に対する列車のブレーキ制御を常用ブレーキによ り自動的に行ったあと，許容速度以下に減速された場

\section{合には自動的に緩解}

が一応の到達点とされている.

こうしたバック・アップ対策の導入がそれ自体の設定 エラー, 故障時のエラー, 運転行動様式の変容に伴うエ ラーなど新たなヒューマン・エラーをもたらす危険は残 るが, ガイドウェイ方式は，“閉そく冒進”だけでなく

“速度超過”, “障害回避”に関しても, バック・アップ 対策の導入に適した特性を備えているといえる。

\section{4-3. 事故対策の問題点}

しかし，バック・アップ機能の挔充を主体とした鉄道 における近年の事故対策が，必ずしも円滑に，效率的に 進められたとはいえない。

主要な反省は, 従来の事故対策が概して巨大事故の “緊急対策”として性急かつ個別的に導入されたため, マン・マシン機能配分上の不適切さや機能の不十分さを 
残す一方で，機能の偏りや重複をもたらし，全体として 所期の効果をあげえなかったということである2).

巨大事故がシステム改善を促すという図式は将来とも 残ろうが, 新しいシステムの導入は単に“局部的な変 更”ではなく“旧来のシステムの大部分は活用するもの の 1 つの全く新しいトータル・システムに置き換える” ことになるという認識をもって，性急さを排した総合的 体系的な準備の下に進められる必要がある。新幹線の建 設はこれの成功例といえよう。

\section{5. 鉄道安全の将来}

むすびに代えて，ヒューマン・エラーをめぐる鉄道シ ステムの事故対策の将来についてつぎの 3 つの点を強調 したい.

第 1 亿，“事故分析”は，“事故はシステムの欠陥を教 えるもの”という冷静な立場に立って, 有識者, 行政, 市民, 労使など各層の代表から構成される独立の専門技 術調査機関によって, 単に事故の “発生経過”之 “原因” を究明するためだけでなく，“システムの欠宿”とてれ に対する “改善の方向”をも明確にする目的で進められ る必要があるということである6゙.

第 2 は，事故対策の方向についてである．事故対策が 多面的であるべきであるてとは論をまたないが，ガイド ウェイ方式の宿命的な欠点がまだ克服されていない鉄道 システムの現状では，ヒューマン・エラーを事故に直結 させないための“バック・アップ対策”の整備に重点をお くことが最も有効であると思われる。また，鉄道システ ムはてれを受容しやすい特性を備えていると見られる。 そして第 3 は，“事故対策” は，個別的でなく，長期
的なシステム改善構想の一環として周到に準備されたう えで実施される必要があるということである。てれには 事例分析だけでなく過去の事故データやシステムの現状 に関するデータによる “大数分析”之“事故の予測”, さらに実験・調查・シミュレーションによる“対策の効 果予測”が不可欠であり，乙れらのアプローチの展開が 強く望まれる1,3,4).

\section{参考文献}

1）原口建之, 他：ヒューマン・エラーの発生率に対 する一考察一運転保安システムの安全性評価一，鉄 道学働科学, $32,147 \sim 168,1978$.

2）池田敏久, 大獄ヒサ：動力車乗務員の誤扱い事故 防止のためのバックアップ・システムの考え方，鉄 道学働科学研究資料, $74 \sim 11,1974$.

3）池田敏久, 他: 保安体系評価の研究（III）一構内 入換における「事故の予測」一, 鉄道学㗢科学, $31,13 \sim 42,1977$.

4）池田敏久：鉄道のシステムと災害, 労㗢の科学, 34(6), 24 28, 1979.

5）柏木繁男：マン・マシン事故の分析と管理（学働 科学叢書 40 ), 労働科学研究所, 1975 .

6）清宮栄一, 他：運転事故の心理学的研究, 鉄道学 働科学, 19, 1966.

7）日本国有鉄道：鉄道の安全について（部内資料）, 日本国有鉄道, 1979.

8）運転局保安課：運転事故・運転阻害統計一昭和52 年度一（部内資料），日本国有鉄道，1979。

9）柳田邦男：新幹線事故 (中公新書410), 中央公論 社, 1978. 